AgriiHealth

ISSN 2722-0656 (Print) 2722-0648 (Online)

\title{
Pengaruh Lokasi Geografis dan Vegetasi terhadap Sifat Fisikokimia Madu dari Ciwidey dan Bogor
}

\author{
Emanuela Rae Alodia*, Anas Bunyamin dan Efri Mardawati
}

Program Studi Teknologi Industri Pertanian, Fakultas Teknologi Industri Pertanian, Universitas Padjadjaran, Bandung, Indonesia

Diterima: 5 Oktober 2020; Disetujui: 23 Oktober 2020

\begin{abstract}
Abstrak
Sifat fisikokimia merupakan salah satu parameter kualitas madu yang dapat memberikan dampak pada pemasaran madu dan ekonomi masyarakat di Ciwidey dan Bogor. Sifat fisikokimia dipengaruhi oleh asal madu, meliputi lokasi geografis dan vegetasinya. Penelitian ini bertujuan untuk mengetahui perbedaan sifat fisikokimia madu dari daerah Ciwidey dan Bogor yang merupakan madu multiflora dengan dominansi vegetasi yang berbeda yaitu kaliandra untuk madu Ciwidey dan randu untuk madu Bogor. Data dianalisis secara deskriptif dan kuantitatif menggunakan uji t independen untuk data yang berdistribusi normal (kadar air dan kadar gula pereduksi). Data yang tidak berdistribusi normal (analisis warna dan nilai keasaman) diuji secara non-parametrik dengan Mann Whitney-U. Hasil penelitian menunjukkan bahwa madu Bogor memiliki sifat fisikokimia yang lebih baik dan memenuhi Standar Nasional Indonesia (SNI) 8664:2018 yaitu dengan kadar air sebesar $15,15 \%$ b/b, analisis warna $L^{*} 35,26 ; a^{*} 28,66 ; b^{*} 59,46 ; c^{*} 66,01 ; h^{*} 64,27^{\circ}$, kadar gula pereduksi sebesar 78,78\%, nilai keasaman sebesar 35,56 mL NaOH kg-1 , skrining fitokimia menunjukkan hasil positif terhadap alkaloid, flavonoid, fenol dan tanin, serta hasil analisis GC-MS menunjukkan tiga kandungan yang paling signifikan yaitu hydroxymethylfurfural sebesar $48,26 \%$, levoglucosan sebesar $13,58 \%$ dan ammonium carbamate sebesar $9,18 \%$.
\end{abstract}

Kata kunci: lokasi geografis; madu; sifat fisikokimia; vegetasi

\section{Geographical Location and Vegetation Effects of Bogor and Ciwidey Honey to the Physicochemical Properties}

\begin{abstract}
Physicochemical properties are one of the parameters of honey quality that impacts the sales of honey as well as the economy condition of the society in Ciwidey and Bogor. The physicochemical properties of honey are significantly influenced by the origin of the honey, including its geographical location and vegetation. This study aims to determine the physicochemical properties between multiflora honey from Ciwidey and Bogor with different source of nectar where Ciwidey honey is dominated by calliandra nectar while Bogor honey is dominated by kapok nectar. Data were analyzed with descriptive and quantitative method using independent $t$ test for data with normal distribution (water content and reducing sugar content). Data that were not normally distributed (color analysis and acidity value) were tested non-parametrically with the Mann Whitney-U. The results showed that Bogor honey has the better physicochemical properties and meets Indonesian National Standard (Standar Nasional

\footnotetext{
*Corresponding author: emanuelaraealodia@gmail.com
}

Cite this as: Alodia, E. R., Bunyamin, A., \& Mardawati, E. (2020). Pengaruh Lokasi Geografis dan Vegetasi terhadap Sifat Fisikokimia Madu dari Ciwidey dan Bogor. AgriHealth: Journal of Agri-food, Nutrition and Public Health, 1(2), 71-80. doi: http://dx.doi.org/10.20961/agrihealth.v1i2.44700
\end{abstract}


Indonesia, SNI) 8664:2018, with a water content of $15.15 \% \mathrm{w} / \mathrm{w}, L^{*}$ values of $35.26, a^{*}$ value of $28.66, b^{*}$ value of $59.46, c^{*}$ value of $66.01, h^{*}$ value of $64.27^{\circ}$, reducing sugar content of $78.78 \%$ and acidity value of $35.56 \mathrm{~mL} \mathrm{NaOH} \mathrm{kg}^{-1}$. Phytochemical screening showed positive results on alkaloid, flavonoid, phenol and tannin, and the results of GC-MS analysis showed three significant compounds which are hydroxymethylfurfural of $48.26 \%$, levoglucosan of $13.58 \%$ and ammonium carbamate of $9.18 \%$.

Keywords: geographical location; honey; physicochemical properties; vegetation

\section{PENDAHULUAN}

Madu adalah cairan manis lengket yang dihasilkan lebah madu atau serangga lainnya dari nektar bunga (Ambarwati et al., 2014). Menurut Kucuk et al. (2007) madu berfungsi sebagai antibakterial, antioksidan, antitumor, antifungal, antiviral dan antiinflamasi sehingga madu menjadi salah satu bahan alami yang dapat digunakan secara luas. Fungsi madu yang luas tersebut dipengaruhi oleh sifat fisikokimia yang didapat dari jenis tanaman yang tumbuh di lingkungan budidaya madu (Azis, 2018). Semakin tinggi suatu daerah maka suhu akan semakin menurun sehingga madu lebih mudah menyerap air (Evahelda et al., 2017). Penyerapan air akan berpengaruh kepada nilai keasaman karena semakin tinggi kadar air maka khamir akan semakin mudah untuk melakukan fermentasi dan menurunkan nilai pereduksi (Savitri et al., 2017).

Jawa Barat merupakan salah satu provinsi yang memiliki kondisi geografis bervariasi dengan kawasan pantai utara sebagai dataran rendah dan bagian tengah daerah Jawa Barat sebagai dataran tinggi (Aris et al., 2015). Hal tersebut menyebabkan Jawa Barat menjadi salah satu daerah yang baik untuk meneliti efek lokasi geografis dan vegetasi budidaya madu terhadap sifat fisikokimianya. Data jumlah peternak madu lebah di Jawa Barat sejauh ini belum bisa diperoleh dari instansi terkait di Provinsi Jawa Barat. Data yang diperoleh sementara berupa potensi hasil hutan berupa smadu dari Kabupaten Bandung dengan produksi sebesar 1.080,00 kg pada tahun 2015 (BPS Provinsi Jawa Barat, 2015).

Jaringan Madu Hutan Indonesia kepada Novandra dan Widnyana (2013) menyampaikan bahwa madu yang diproduksi tiap tahunnya sekitar 208 ton, namun yang berhasil dipasarkan sekitar 27 ton atau 13\% dari total yang dihasilkan. Hal tersebut karena jika ditinjau dari permintaan industri jamu dan kosmetika, sifat fisikokimia madu yang beredar di pasaran belum memenuhi standar. Beberapa penyebabnya adalah karena kadar air berlebih dan kotoran yang seringkali ditemukan dalam madu seperti sarang lebah, kaki lebah dan kotoran lainnya.

Penentu dari sifat fisikokimia madu adalah sumber nektar tumbuhan, lokasi, musim dan iklim sehingga komposisi dan sifat fisikokimia setiap madu akan berbeda-beda (El Sohaimy et al., 2015; Pavlova et al., 2018). Kondisi Indonesia dengan kelembapan udara yang cukup tinggi yaitu 60-80\% memengaruhi kadar air pada madu sehingga kadarnya berkisar pada $25-29 \%$ yang berarti di atas Standar Nasional Indonesia (SNI) Madu No. 013545 Tahun 1994 di mana kadar air maksimal adalah $22 \%$. Tingginya kadar air pada madu memengaruhi kandungan madu terutama kecepatan madu untuk terfermentasi.

Provinsi Jawa Barat yang memproduksi madu dalam jumlah yang cukup besar perlu diketahui sifat fisikokimianya sehingga data tersebut dapat digunakan oleh peternak madu lebah sebagai referensi dalam pengembangan dan perbaikan budidaya madu lebah. Upaya tersebut akan meningkatkan kualitas madu yang kemudian berdampak pada peningkatan ekonomi masyarakat di Ciwidey dan Bogor. Hasil penelitian juga dapat digunakan oleh akademisi dan peneliti untuk pemanfaatan produk turunan dari madu dan sebagai landasan untuk penelitian lanjutan. Penelitian ini bertujuan untuk mengetahui perbedaan sifat fisikokimia madu dari daerah Ciwidey dan Bogor yang merupakan madu multiflora dengan dominansi vegetasi yang berbeda yaitu kaliandra untuk madu Ciwidey dan randu untuk madu Bogor.

\section{BAHAN DAN METODE}

Kedua sampel madu merupakan madu multiflora yaitu madu Ciwidey yang diperoleh dari pemilik lebah $\mathrm{X}$ dan madu Bogor yang diperoleh dari pemilik lebah Y. Madu Ciwidey 
terletak pada ketinggian 1000-1500 meter di atas permukaan laut (m dpl), dengan suhu berkisar $22-32^{\circ} \mathrm{C}$, kelembapan udara $80-90 \%$ dan curah hujan sebesar 2000-2450 mm tahun ${ }^{-1}$, pemanenan madu Ciwidey dilakukan pada bulan Oktober 2019 dengan suhu $25^{\circ} \mathrm{C}$, madu Ciwidey didominasi vegetasi tanaman kaliandra. Madu Bogor terletak pada ketinggian 190-330 m dpl, dengan suhu berkisar $21,8-30,4^{\circ} \mathrm{C}$, kelembapan udara $70 \%$ dan curah hujan sebesar 3500-4000 $\mathrm{mm}$ tahun $^{-1}$, pemanenan madu Bogor dilakukan pada bulan Desember dengan suhu $30^{\circ} \mathrm{C}$, madu Bogor didominasi vegetasi tanaman randu.

Analisis data pada penelitian ini dilakukan secara deskriptif dan kuantitatif menggunakan analisis uji $t$ independen untuk yang berdistribusi normal dan Mann Whitney- $U$ untuk data yang tidak berdistribusi normal menggunakan aplikasi SPSS. Sifat fisikokimia madu yang dianalisis meliputi kadar air, warna, kadar gula pereduksi, keasaman, skrining fitokimia (alkaloid, flavonoid, fenol, tanin dan saponin) dan analisis GC-MS.

\section{Kadar air}

Sampel madu sebanyak 2 gr dimasukkan ke dalam botol timbang, kemudian dipanaskan dalam oven pada suhu $110^{\circ} \mathrm{C}$ selama 2 jam, setelah itu dinginkan selama 10 menit dalam eksikator dan ditimbang, panaskan kembali selama satu jam lalu dilakukan pendinginan dan penimbangan sampai berat konstan.

$$
\text { Kadar Air }(\% b b)=\frac{W-(W 1-W 2)}{W} \times 100 \%
$$

\section{Warna}

Analisis warna sampel dilakukan menggunakan chromameter untuk skala pengukuran $\mathrm{L}^{*}$, a* dan $\mathrm{b}^{*}$. Chromameter mengukur warna sampel sebanyak 2 kali yaitu bagian depan dan belakang kuvet. Derajat perbedaan warna antar kedua sampel serta turunan untuk nilai $\mathrm{c}^{*}$ dan $\mathrm{h}^{*}$ dihitung menggunakan rumus berikut:

$$
\begin{aligned}
\Delta E_{a b}^{*} & =\sqrt{\left(\Delta L^{*}\right)^{2}+\left(\Delta a^{*}\right)^{2}+\left(\Delta b^{*}\right)^{2}} \\
c^{*} & =\sqrt{a^{* 2}+b^{* 2}} \\
h^{*} & =\arctan \frac{b^{*}}{a^{*}}
\end{aligned}
$$

\section{Kadar gula pereduksi}

Larutan A dibuat dengan menimbang sampel madu sebanyak 2 gr kemudian dilarutkan dengan $100 \mathrm{~mL}$ akuades pada labu ukur 250 mL. Tambahkan $5 \mathrm{~mL} \mathrm{~Pb}$ asetat $5 \%$ pada campuran tersebut dan dikocok. Setelah itu tambahkan $5 \mathrm{~mL} \mathrm{Na} \mathrm{HPO}_{4} 5 \%$ pada campuran tersebut dan dilanjutkan dengan pengocokan selama 1 menit.

Larutan A diambil $25 \mathrm{~mL}$ kemudian ditambahkan $25 \mathrm{~mL}$ luff schoorl. Tambahkan $10 \mathrm{~mL} \mathrm{KI} 30 \%$ dan $25 \mathrm{ml} \mathrm{H}_{2} \mathrm{SO}_{4} 6 \mathrm{~N}$ ke dalam larutan tersebut. Larutan kemudian dititrasi dengan $\mathrm{Na}_{2} \mathrm{~S}_{2} \mathrm{O}_{3} \quad 0,1 \mathrm{~N}$ sampai warna berubah menjadi kuning jerami. Tambahkan $1 \mathrm{~mL}$ indikator amilum 1\% dan titrasi dilanjutkan sampai warna berubah menjadi putih susu, volume titrasi dicatat dan dihitung kadar gula pereduksinya menggunakan rumus berikut:

$$
\begin{gathered}
a=\frac{(\text { volume blanko }- \text { volume sampel }) \times N}{0,1 N} \\
\% \text { gula pereduksi }=\frac{b \times F P}{w(g) \times 1000} \times 100 \%
\end{gathered}
$$

\section{Keasaman}

10 gr sampel dilarutkan dalam $100 \mathrm{~mL}$ akuades kemudian ditempatkan dalam labu ukur $100 \mathrm{~mL}$. Ambil $10 \mathrm{~mL}$ larutan kemudian tambahkan indikator PP dan titrasi menggunakan $\mathrm{NaOH}$.

\section{Skrining alkaloid}

Sampel madu sebanyak 10 tetes dimasukkan dalam dua tabung reaksi dan masingmasing ditambahkan ammonia 10\% sebanyak $1 \mathrm{~mL}$ dan $\mathrm{HCl} 2 \mathrm{~N}$ sebanyak $0,5 \mathrm{~mL}$. Pada campuran tersebut ditambahkan pereaksi dragendorff pada satu tabung dan pereaksi mayers untuk tabung lainnya. Perubahan warna menjadi coklat menandakan positif terkandung alkaloid.

\section{Skrining flavonoid}

Sampel madu sebanyak 1 gr dimasukkan ke dalam tabung reaksi dan ditambahkan butiran magnesium dan $\mathrm{HCl} 2 \mathrm{~N}$. Larutan tersebut disaring dan ditambahkan amil alkohol. Perubahan warna menjadi merah/jingga menunjukkan adanya kandungan flavonoid (Munte et al., 2015). 


\section{Skrining fenol}

Sampel madu sebanyak 3 tetes dimasukkan ke dalam tabung reaksi dan ditambahkan $\mathrm{FeCl}_{3}$ 5\% sebanyak dua tetes. Sampel positif mengandung komponen fenolik jika terbentuk warna hijau, hitam kebiruan atau hitam kuat (Munte et al., 2015).

\section{Skrining tanin}

Sampel madu sebanyak 3 tetes dimasukkan ke dalam tabung reaksi dan ditambahkan $\mathrm{FeCl}_{3}$ $1 \%$ sebanyak dua tetes. Sampel positif mengandung komponen tanin jika terbentuk warna hijau (Putri dan Hidajati, 2015).

\section{Skrining saponin}

Sampel madu sebanyak 10 tetes ditambahkan $5 \mathrm{~mL}$ akuades hangat kemudian kocok selama 1 menit. Jika terbentuk busa maka terdapat kandungan saponin.

\section{Analisis GC-MS}

Analisis GC-MS dilakukan di Pusat Perlebahan Nasional (PUSBAHNAS) Bogor. Mengacu pada penelitian Kus dan Jerkovic (2018) menggunakan model kromatografi yang dilengkapi dengan Mass Selective Detector
(MSD) dan kolom kapiler. MSD dioperasikan pada $70 \mathrm{eV}$, suhu sumber ion sebesar $230^{\circ} \mathrm{C}$ dan kisaran massa 30-300 amu. Sampel diinjeksikan ke dalam ruang injeksi pada permukaan GC dengan jarum hipodermik, kemudian sampel diuapkan dan dipisahkan serta dianalisis bentuk puncak yang terekam.

\section{HASIL DAN PEMBAHASAN}

\section{Kadar air}

Tabel 1 menunjukkan sifat fisikokimia madu Ciwidey dan Bogor. Hasil pengujian menunjukkan bahwa kadar air berat basah madu Bogor adalah sebesar $15,15 \%$ dan madu Ciwidey adalah sebesar 17,73\%. Diketahui kadar air berat kering untuk madu Bogor adalah $17,97 \%$ dan untuk madu Ciwidey sebesar $21,56 \%$ sehingga kedua madu memenuhi kriteria SNI 8664:2018 yaitu dibawah $22 \%$. Perhitungan statistik uji $\mathrm{t}$ independen menghasilkan $\mathrm{t}$ hitung $>\mathrm{t}$ tabel yaitu $\mathrm{t}$ hitung sebesar 12,27 dan $t$ tabel sebesar 2,78 sehingga dapat disimpulkan bahwa terdapat perbedaan nyata untuk rata-rata nilai kadar air madu Bogor dengan madu Ciwidey.

Tabel 1. Sifat fisikokimia madu Ciwidey dan Bogor

\begin{tabular}{ccccccccc}
\hline \multirow{2}{*}{ Madu } & $\begin{array}{c}\text { Kadar air } \\
(\% \mathrm{~b} / \mathrm{b})\end{array}$ & $\mathrm{L}^{*}$ & $\mathrm{a}^{*}$ & $\mathrm{~b}^{*}$ & $\mathrm{c}^{*}$ & $\mathrm{~h}^{*}\left(^{\circ}\right)$ & $\begin{array}{c}\text { Kadar gula } \\
\text { pereduksi } \\
(\%)\end{array}$ & $\begin{array}{c}\text { Nilai } \\
\text { keasaman } \\
\left(\mathrm{mL} \mathrm{NaOH} \mathrm{kg} \mathrm{k}^{-1}\right)\end{array}$ \\
\hline Ciwidey & $17,73^{\mathrm{a}}$ & $49,19^{\mathrm{a}}$ & $41,43^{\mathrm{a}}$ & $84,13^{\mathrm{a}}$ & $93,77^{\mathrm{a}}$ & $63,78^{\mathrm{a}}$ & $69,96^{\mathrm{a}}$ & $93,27^{\mathrm{a}}$ \\
& $\pm 0,34$ & $\pm 0,01$ & $\pm 0,02$ & $\pm 0,16$ & $\pm 0,14$ & $\pm 0,03$ & $\pm 4,85$ & $\pm 0,64$ \\
Bogor & $15,15^{\mathrm{b}}$ & $35,26^{\mathrm{a}}$ & $28,66^{\mathrm{a}}$ & $59,46^{\mathrm{a}}$ & $66,01^{\mathrm{a}}$ & $64,27^{\mathrm{a}}$ & $78,78^{\mathrm{a}}$ & $35,56^{\mathrm{a}}$ \\
& $\pm 0,14$ & $\pm 0,18$ & $\pm 0,04$ & $\pm 0,20$ & $\pm 0,09$ & $\pm 0,06$ & $\pm 5,79$ & $\pm 0,00$ \\
\hline
\end{tabular}

Keterangan: Angka yang diikuti huruf yang berbeda pada kolom yang sama menunjukkan adanya beda nyata pada taraf sig $\alpha=0,05$

Kondisi pada saat pemanenan dan budidaya memengaruhi kadar air. Madu Ciwidey dipanen saat musim hujan dengan kelembapan tinggi $80-90 \%$ sehingga madu memiliki sifat higroskopis menyerap lebih banyak air dengan demikian memiliki kadar air yang tinggi. Menurut Ansar et al. (2006) kelembapan yang tinggi mengindikasikan keberadan uap air yang semakin tinggi sehingga menyebabkan terjadinya penyerapan air dari luar produk. Menurut Prasetya (2014), kadar air yang rendah akan menjaga madu dari kerusakan untuk waktu yang relatif lebih panjang, karena kadar air yang rendah tidak merangsang aktivitas khamir untuk tumbuh dan berkembang. Hasil pengujian kadar air ini juga sesuai dengan penelitian Chayati (2008) bahwa kadar air madu kaliandra sebesar 26,52\% lebih tinggi dibandingkan madu randu sebesar 20,77\%. Seperti yang diketahui bahwa madu Ciwidey didominasi dengan pakan dari nektar tanaman kaliandra dan madu Bogor didominasi dengan pakan dari nektar tanaman randu.

\section{Warna}

Gonzales et al. (2005) mengelompokan nilai L* madu menjadi dua, yaitu madu berwarna terang jika memiliki $\mathrm{L}^{*}>50$ dan madu berwarna gelap jika nilai $\mathrm{L}^{*}<50$. Sesuai dengan pernyataan Gonzales et al. (2005), maka pengelompokan nilai L* madu Bogor dan Ciwidey termasuk ke dalam 
kategori gelap karena nilai rata-rata $\mathrm{L}^{*}$ madu Bogor adalah 35,26 dan nilai rata-rata $\mathrm{L}^{*}$ madu Ciwidey adalah 49,19 yang adalah kurang dari 50. Hasil penelitian menunjukkan bahwa nilai a* dan $b^{*}$ yang paling tinggi diperoleh dari madu Ciwidey dengan nilai kemerahan $\left(\mathrm{a}^{*}\right)$ sebesar 41,43 dan kekuningan (b*) sebesar 84,13 (Tabel 1). Derajat perbedaan warna antara kedua sampel dihitung $\left(\Delta E_{a b}^{*}\right)$ dan menghasilkan nilai sebesar 31,08 . Konversi nilai $a^{*}$ dan $b^{*}$ menjadi $\mathrm{c}^{*}$ (kroma) dan $\mathrm{h}^{*}$ (hue) menghasilkan nilai c* untuk madu Ciwidey sebesar 93,77 dan untuk madu Bogor sebesar 66,01 sementara nilai $\mathrm{h}^{*}$ untuk madu Ciwidey sebesar $63,78^{\circ}$ dan madu Bogor sebesar $64,27^{\circ}$.

Nilai kroma menurut Swandari et al. (2017) akan meningkat jika warna objek terang sehingga dapat diketahui bahwa madu Ciwidey memiliki warna yang lebih terang dibandingkan madu Bogor, sesuai dengan nilai $\mathrm{L}^{*}$ yang dihasilkan. Hue adalah panjang gelombang dominan dari warna yang dapat dilihat oleh mata manusia, penggolongan warna hue terbagi menjadi warna merah dengan rentang antara $0^{\circ}$, kuning memiliki rentang antara $60^{\circ}$, hijau memiliki rentang antara $120^{\circ}$, cyan memiliki rentang antara $180^{\circ}$, biru memiliki rentang antara $240^{\circ}$ dan magenta memiliki rentang antara $300^{\circ}$, sehingga nilai derajat hue yang dihasilkan dari madu Ciwidey dan Bogor tergolong sebagai warna kuning (Mather, 2004). Hasil analisis statistik uji nonparametrik yaitu Mann Whitney- $U$ menghasilkan signifikansi untuk nilai $\mathrm{L}^{*}, \mathrm{a}^{*}, \mathrm{~b}^{*}, \mathrm{c}^{*}$ dan $\mathrm{h}^{*}$ sebesar 0,33 yaitu sig >0,05 sehingga dapat dikatakan tidak terdapat perbedaan signifikan untuk kedua warna madu.

Perbedaan warna madu dipengaruhi oleh kandungan mineral, pengolahan madu dan jenis tanaman asal sumber nektar (Kuntadi, 2002). Pendapat Kuntadi (2002) mengenai perbedaan warna madu dipengaruhi oleh kandungan mineral dan jenis tanaman asal sumber nektar dibuktikan dengan penelitian Yeboah-Gyan dan Marfo (1998). Madu berwarna gelap yang merupakan madu multiflora dengan salah satu vegetasi asalnya adalah tanaman randu (Ceiba pentandra) memiliki rata-rata kandungan mineral yang lebih banyak dibandingkan madu berwarna terang dengan nilai $314,3 \mathrm{mg} \mathrm{kg}{ }^{-1}$. Mineral yang terkandung pada madu berwarna gelap adalah kalsium, fosfor, magnesium, sodium, potassium, besi, tembaga dan mangan. Sehingga hasil penelitian ini sesuai dengan penelitian YeboahGyan dan Marfo (1998) di mana madu yang lebih gelap didapati dari asal vegetasi tanaman randu.

\section{Kadar gula pereduksi}

Hasil dari kadar gula pereduksi untuk madu Bogor adalah 78,78\% dan untuk madu Ciwidey adalah sebesar 69,96\% yang keduanya memenuhi persyaratan menurut SNI 8664:2018 yaitu memiliki kadar gula pereduksi sekurangnya $65 \%$ (Tabel 1). Hasil analisis statistik uji $t$ independen adalah $\mathrm{t}$ hitung $<\mathrm{t}$ tabel yaitu $\mathrm{t}$ hitung bernilai -2.03 dan $t$ tabel bernilai 2,78 sehingga tidak terdapat perbedaan rata-rata kadar gula pereduksi antara madu Bogor dengan madu Ciwidey.

Wulandari et al. (2017) menyampaikan bahwa aktivitas khamir yaitu Zygosaccharomyces dalam madu dapat tumbuh dan berkembang dengan cepat jika kandungan airnya tinggi yang disebabkan oleh kelembapan lokasi panen madu tersebut sehingga khamir dapat berfermentasi dan mendegradasi glukosa serta fruktosa menjadi alkohol dan $\mathrm{CO}_{2}$ yang berakibat pada berkurangnya kadar gula pereduksi madu. Pendapat Wulandari et al. (2017) sesuai dengan hasil yang didapatkan dimana madu Ciwidey memiliki kondisi panen dengan kelembapan yang lebih tinggi dibandingkan dengan madu Bogor sehingga kandungan glukosa dan fruktosa pada madu Ciwidey diduga telah terdegradasi menjadi alkohol dan $\mathrm{CO}_{2}$.

Hasil kadar gula pereduksi ini juga sesuai dengan penelitian Chayati (2008) dimana kadar gula pereduksi madu kaliandra adalah sebesar $53,49 \%$ dan kadar gula pereduksi madu randu adalah sebesar $65,91 \%$. Seperti diketahui bahwa madu Ciwidey didominasi vegetasi kaliandra dan madu Bogor didominasi vegetasi randu sehingga terbukti bahwa jenis nektar yang berbeda menghasilkan kadar gula pereduksi yang berbeda pula dimana pada penelitian ini madu hasil vegetasi kaliandra menghasilkan kadar gula pereduksi yang lebih rendah dibandingkan madu hasil vegetasi randu.

Kadar gula pereduksi juga dipengaruhi oleh nektar bunga dimana dapat terjadi hidrolisis sukrosa yang terdapat pada getah floem oleh enzim invertase yang terdapat pada dinding nektar (Woodson dan Wang, 1987; Strum et al., 1999; Nicolsson, 2002; De la Barrera dan Nobel, 2004). Corbet (1978) menyampaikan perbedaan kadar gula pada nektar dipengaruhi oleh 
kelembapan udara dan temperatur udara, hasil penelitiannya menunjukkan bahwa pada keadaan lingkungan dengan kelembapan tinggi dan temperatur yang cukup tinggi menghasilkan konsentrasi gula yang lebih tinggi. Hasil penelitian ini sesuai dengan pendapat Corbet (1978) tersebut, madu Bogor dengan kondisi kelembapan tinggi dan temperatur yang lebih tinggi menghasilkan kadar gula pereduksi yang lebih tinggi dibandingkan madu Ciwidey.

\section{Keasaman}

Hasil uji keasaman dari madu Bogor adalah $35,56 \mathrm{~mL} \mathrm{NaOH} \mathrm{kg}^{-1}$ dan madu Ciwidey sebesar 93,27 mL NaOH kg-1 sehingga dapat diketahui bahwa madu Bogor memenuhi kriteria SNI 8664:2018 yaitu dibawah $50 \mathrm{~mL} \mathrm{NaOH} \mathrm{kg}{ }^{-1}$ namun madu Ciwidey tidak memenuhi persyaratan SNI 8664:2018 dan memiliki selisih 43,49 mL NaOH kg-1 dengan SNI 8664:2018 (Tabel 1). Hasil uji statistik non-parametrik dilakukan dengan metode Mann Whitney- $U$ memberikan keputusan bahwa distribusi keasaman di semua kategori madu (Ciwidey dan Bogor) adalah sama dengan signifikansi 0,1 dapat dikatakan juga bahwa tidak terdapat perbedaan signifikan antara kedua madu.

Kadar keasaman merupakan indikator terjadinya proses fermentasi yaitu proses transformasi alkohol menjadi asam organik (Wulandari et al., 2017). Menurut National Honey Board (2006), keasaman madu disebabkan oleh beberapa jenis asam yaitu asam amino yang didominasi dengan prolin serta asam organik yang didominasi dengan asam glukonat, asam glukonat ini diproduksi melalui kerja enzim glukosa oksidase dalam glukosa. Salah satu penyebab terjadinya perbedaan kadar keasaman adalah tingkat kelembapan lokasi budidaya dan juga kondisi penyimpanan madu tersebut setelah dipanen. Tingkat kelembapan yang lebih tinggi mengakibatkan madu lebih mudah menyerap air dan menyebabkan terjadinya fermentasi, dibuktikan dengan nilai keasaman madu Ciwidey lebih tinggi dibandingkan dengan madu Bogor.

Penyimpanan madu Ciwidey dilakukan lebih lama pada suhu ruang yaitu 3 bulan dari pemanenan bulan Oktober 2019 sampai penelitian di bulan Januari 2020. Nektar dari asal madu juga berpengaruh apabila terdapat jamur pada nektar maka nilai keasaman akan semakin rendah juga karena adanya fermentasi. Hasil penelitian Sobhy et al. (2018) menyebutkan bahwa jamur yang diinokulasikan pada nektar menghasilkan $\mathrm{pH}$ yang menurun dari 5,76 menjadi 3,91 yang disebabkan jamur menghasilkan konsentrasi asam amino yang lebih tinggi dibandingkan nektar kontrol.

\section{Skrining fitokimia}

Hasil skrining fitokimia yang dilakukan secara kualitatif menunjukkan bahwa madu Ciwidey dan madu Bogor memiliki hasil positif pada alkaloid, flavonoid, fenol dan tanin. Secara umum madu Ciwidey menunjukkan hasil perubahan warna yang lebih signifikan dibandingkan madu Bogor sehingga diduga madu Ciwidey memiliki kandungan fitokimia yang lebih banyak dibandingkan madu Bogor (Tabel 2).

Tabel 2. Skrining fitokimia madu Ciwidey dan Bogor

\begin{tabular}{cccccccc}
\hline \multicolumn{7}{c}{ Fitokimia } \\
\hline \multirow{2}{*}{ No. } & \multirow{2}{*}{ Madu } & \multicolumn{7}{c}{ Alkaloid } & Flavonoid & Fenol & Tanin & Saponin \\
\cline { 2 - 8 } & & Dragendorff & Mayer & & + & + & - \\
\hline 1. & Ciwidey & ++ & ++ & + & +++ & + & - \\
\hline
\end{tabular}

Keterangan: - = Tidak teridentifikasi mengandung senyawa aktif; $+=$ Teridentifikasi lemah mengandung senyawa aktif; $++=$ Teridentifikasi sedang mengandung senyawa aktif; $+++=$ Teridentifikasi kuat mengandung senyawa aktif

\section{GC-MS}

Analisis GC-MS dilakukan terhadap madu Bogor karena madu Bogor memiliki sifat fisikokimia yang memenuhi kriteria SNI
8664:2018 dibandingkan madu Ciwidey. Hasil analisis GC-MS menunjukkan tiga senyawa yang memiliki konsentrasi paling tinggi yaitu hydroxymethylfurfural (HMF), levoglucosan dan ammonium carbamate (Gambar 1). 


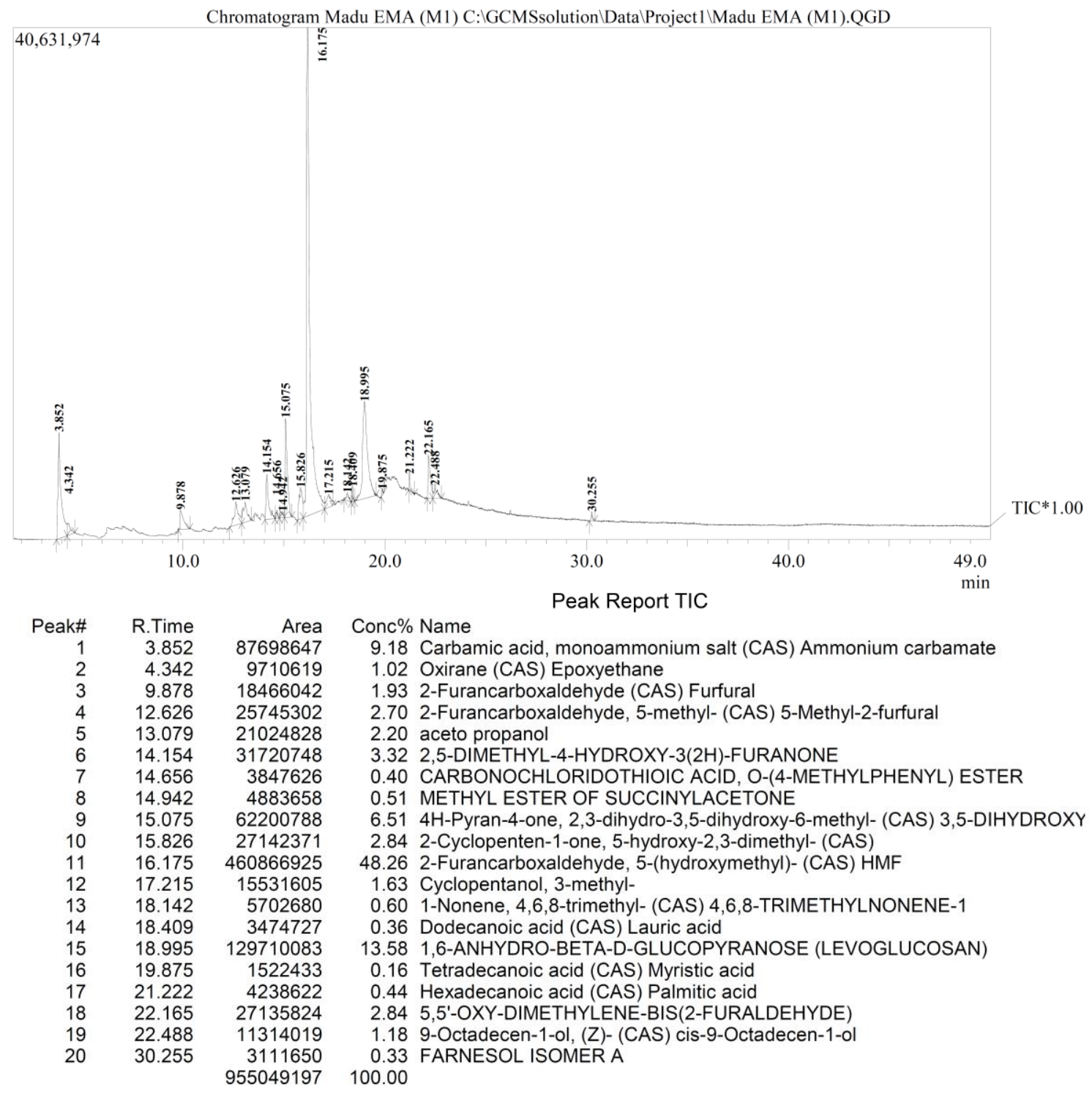

Gambar 1. Analisis GC-MS Madu Bogor

HMF yang diperoleh pada analisa GC-MS adalah sebesar 48,26\%. Kandungan HMF yang cukup tinggi bisa diakibatkan oleh kondisi dan lama penyimpanan madu serta perlakuan pemanasan (Khan et al., 2015). Namun madu ini kemungkinan besar dipengaruhi kondisi penyimpanan dalam suhu ruang karena tidak ada perlakuan pemanasan sama sekali terhadap madu. Singh dan Bath (1997) mengatakan bahwa pembentukan HMF biasanya disebabkan oleh komposisi gula dan keasaman yang tinggi. Terdapatnya kandungan HMF pada madu seringkali diasosiasikan dengan madu yang telah rusak, namun hal tersebut dibantah oleh Gonnet (1963) yang menemukan bahwa HMF juga ditemukan dalam madu yang baru dipanen terutama pada madu dari negara tropis seperti Indonesia.

Levoglucosan sebesar $13,58 \%$ adalah glukosida yang diperoleh dari proses pirolisis selulosa atau pati (Ward, 1963). Levoglucosan tersedia sebagai gula yang melimpah dan merupakan substrat fermentasi (Layton et al., 2011) dan dapat dikonversi menjadi glukosa dengan hidrolisis (Dai et al., 2009). Ammonium carbamate diperoleh sebesar 9,18\%. Menurut (Johnson et al., 1991) ammonium carbamate diproduksi sebagai zat antara dalam sintesis urea dan hasil dari penelitiannya menunjukkan adanya interaksi antara konsentrasi ammonium carbamate dengan pertumbuhan jamur dimana semakin tingginya konsentrasi ammonium 
carbamate maka jumlah jamur akan menurun, hal ini ditunjukkan dengan penurunan jumlah jamur dari 5,2 $\mathrm{gr} \mathrm{mL}^{-1}$ menjadi 4,4 $\mathrm{gr} \mathrm{mL}^{-1}$ saat diberikan $1,14 \%$ ammonium carbamate dan begitu seterusnya mencapai jumlah jamur 0,4 gr $\mathrm{mL}^{-1}$ saat diberikan $6,84 \%$ ammonium carbamate. Hasil dari GC-MS lainnya yang memiliki keterkaitan dengan penelitian sebelumnya yaitu pada penelitian Gaydou et al. (1981) adalah asam lemak yaitu myristic acid dan palmitic acid yang juga meneliti kandungan pada tanaman randu menggunakan GC-MS.

Sifat fisikokimia dari madu sangat penting untuk diketahui agar sifat yang belum memenuhi SNI dapat dibenahi sehingga produksi madu selanjutnya dapat memenuhi standar dan dapat meningkatkan jumlah madu yang berhasil dipasarkan. Peningkatan penjualan madu yang telah memenuhi SNI akan membantu kesejahteraan masyarakat khususnya peternak madu. Pada penelitian ini diketahui bahwa terdapat satu parameter yang tidak memenuhi SNI yaitu keasaman dari madu Ciwidey yang melebihi batas maksimal, solusi untuk kasus ini adalah dengan menyimpan madu hasil panen pada ruangan yang telah dirancang khusus dilengkapi dengan pengatur suhu dan kelembapan ruangan. Suhu dan kelembapan ruang penyimpanan madu disarankan lebih rendah dari suhu dan kelembapan ruang normal yaitu $20^{\circ} \mathrm{C}$ dan kelembapan $45 \%$.

\section{KESIMPULAN}

Madu yang berasal dari sumber lokasi geografis serta asal vegetasi yang berbeda menghasilkan sifat fisikokimia yang berbeda secara deskriptif walaupun hasil analisis statistik tidak berbeda nyata. Sifat fisikokimia madu Bogor memenuhi SNI 8664:2018 dengan kadar air sebesar $15,15 \% \mathrm{~b} / \mathrm{b}$, kadar gula pereduksi sebesar 78,78\% dan nilai keasaman sebesar 35,56 $\mathrm{mL} \mathrm{NaOH} \mathrm{kg}{ }^{-1}$. Hasil fisikokimia dari madu Bogor lainnya yang tidak tercantum pada SNI 8664:2018 adalah analisis warna $L^{*} 35,26$; $a^{*} 28,66 ; b * 59,46 ; c^{*} 66,01 ; h^{*} 64,27^{\circ}$; skrining fitokimia menunjukkan hasil positif terhadap alkaloid, flavonoid, fenol dan tanin, serta hasil analisis GC-MS menunjukkan tiga kandungan yang paling signifikan yaitu HMF sebesar $48,26 \%$, levoglucosan sebesar $13,58 \%$ dan ammonium carbamate sebesar 9,18\%. Madu Ciwidey tidak memenuhi SNI 8664:2018 pada nilai keasaman yaitu sebesar 93,27 $\mathrm{mL}$ $\mathrm{NaOH} \mathrm{kg}$. Oleh karena itu disarankan untuk menyimpan madu hasil panen di ruang khusus dengan kondisi lebih rendah dari suhu dan kelembapan normal yaitu $20^{\circ} \mathrm{C}$ dan kelembapan $45 \%$. Hasil penelitian ini dapat digunakan oleh peternak madu lebah sebagai referensi dalam pengembangan dan perbaikan budidaya madu lebah. Akademisi dan peneliti juga dapat menggunakan untuk pemanfaatan produk turunan dari madu dan sebagai landasan untuk penelitian lanjutan.

\section{DAFTAR PUSTAKA}

Ambarwati, Utami, R., Meisyaroh, R. P., \& Umaroh, A. K. (2014). Uji aktivitas madu terhadap Escherichia coli dan Aspergilus fumigatus. Seminar Nasional Bioteknologi Universitas Gajah Mada, 1-14. Tersedia dari https://publikasiilmiah.ums.ac.id/handle/1161 $7 / 9733$

Ansar, Budi, R., Zuheid, N., \& Rochmadi. (2006). Pengaruh temperatur dan kelembaban udara terhadap kelarutan tablet Effervescent. Indonesian Journal of Pharmacy, 17(2), 6368. Tersedia dari http://indonesianjpharm.far masi.ugm.ac.id/index.php/3/article/view/344

Aris, A., Arifin, E. N., Hasbullah, M. S., Handayani, N. B., \& Pramono, A. (2015). Demography of Indonesia's Ethnicity. Institute of Southeast Asian Studies. Tersedia dari https://www.researchgate.net/publication/283 788866_Demography_of_Indonesia's_Ethnici ty

Azis, A. (2018). Aktivitas antioksidan, kadar total flavonoid dan kadar total fenolik propolis pada dua jenis lebah (Apis mellifera dan Trigona sp.) dan lokasi berbeda. Sarjana Thesis, Universitas Brawijaya, Malang. Tersedia dari http://repository.ub.ac.id/12295/

BPS - Badan Pusat Statistik Provinsi Jawa Barat. (2015). Statistik Kehutanan Jawa Barat 2015. Tersedia dari https://jabar.bps.go.id/publicati on/2015/10/30/136e 7f877e50d20c0e17a68f/st atistik-daerah-provinsi-jawa-barat-2015.html

Chayati, I. (2008). Sifat fisikokimia madu monoflora dari Daerah Istimewa Yogyakarta dan Jawa Tengah. Agritech, 28(1), 9-14. Tersedia dari https://jurnal.ugm.ac.id/agritech/ article/view/9779\#: :text=Sifat\%2Dsifat\%20 
kimia\%20madu\%20monoflora, $\% 2 \mathrm{C} 30 \% 20 \mathrm{~m}$ $\mathrm{g} \% 2 \mathrm{~F} 100 \% 20 \mathrm{ml}$.

Corbet, S. A. (1978). A bee's view of nectar. Bee World, 59(1), 25-32. https://doi.org/10.1080/ 0005772x.1978.11097683

Dai, J., Yu, Z., He, Y., Zhang, L., Bai, Z., Dong, Z., Du, Y., \& Zhang, H. (2009). Cloning of a novel levoglucosan kinase gene from Lipomyces starkeyi and its expression in Escherichia coli. World Journal of Microbiology \& Biotechnology, 25, 1589. https://doi.org/10.1007/s11274-009-0048-9

De la Barrera, E., \& Nobel, P. S. (2004). Nectar: properties, floral aspects, and speculations on origin. Trends in Plant Science, 9(2), 65-9. https://doi.org/10.1016/j.tplants.2003.12.003

El Sohaimy, S. A., Masry, S. H. D., \& Shehata, M. G. (2015). Physicochemical characteristic of honey from different origins. Annalisis of Agricultural Science, 60(2), 279-287. https:// doi.org/10.1016/j.aoas.2015.10.015

Evahelda, E., Filli, P., Malahayati, N., \& Santoso, B. (2017). Sifat fisik dan kimia madu dari nektar pohon karet di Kabupaten Bangka Tengah, Indonesia. Agritech, 37(4), 363-368. https://doi.org/10.22146/agritech.16424

Gaydou, E. M., Bianchini, J. P., \& Ralaimanarivo, A. (1981). Cyclopropenoid fatty acid in Malagasy baobab: Adansonia frandidieri (Bombacaceae) seed oil. Fette Seifen Anstrichmittel, 84(12), 468-472. https://doi. org/10.1002/lipi.19820841204

Gonnet, M. (1963). L'hydroxymethylfurfural dans les miels. Mise Au Point d'une Methode de Dosage. Les Annales de l'Abeille, INRA Editions, 6(1), 53-67. Tersedia dari https:// hal.archives-ouvertes.fr/hal-00890172

Gonzales, M. L., Terrab, A., Hernanz, D., Fernandez-Recamales, M. A., \& Heredia, F. J. (2005). Multivariate correlation between colour and mineral composition of honey and by their botanical origin. Journal Agricultural Food Chemistry, 53(7), 2574-2580. https:// doi.org/10.1021/jf048207p

Johnson, L. J., Cross, D. L., Jenkins, T. C., Khalilan, A., \& Redmond, L. M. (1991). Effect of ammonium carbamate on nutritive and preservative characteristics of high-moisture coastal bermudagrass hay. Journal of Animal Science, 69(6), 2608-2616. https://doi.org/ $10.2527 / 1991.6962608 \mathrm{x}$

Khan, Z. S., Nanda, V., Bhat, M. S., \& Khan, A. (2015). Kinetic Studies of HMF formation and diastase activity in two different honeys of Kashmir. International Journal of Current Microbiology and Applied Sciences, 4(4), 70-106. Tersedia dari https://www.ijcmas. com/vol-4-4/Zakir\%20S.\%20Khan,\%20et\%2 0al.pdf

Kucuk, M., Kolaylh, S., Karaoglu, S., Ulusoy, E., Baltaci, C., \& Candan, F. (2007). Biological activities and chemical composition of three honeys of different types from Anatolia. Food Chemistry, 100(2), 526-234. https://doi.org/ 10.1016/j.foodchem.2005.10.010

Kuntadi. (2002). Madu: Komposisi, Sifat, dan Khasiatnya. Sylva Tropika Informasi Ilmu Pengetahuan dan Teknologi Populer.

Kus, P. M., \& Jerkovic, I. (2018). New sample preparation method for honey volatiles fingerprinting based on dehydration homogeneous liquid-liquid extraction (DHLLE). Molecules, 23(7), 1769. https:// doi.org/10.3390/molecules23071769

Layton, D. S., Ajjarpu, A., Choi, D. W., \& Jarboe, L. R. (2011). Engineering ethanologenic Escherichia coli for levoglucosan utilization. Bioresource Technology, 102(17), 8318-22. https://doi.org/10.1016/j.biortech.2011.06.011

Mather, P. M. (2004). An introduction computer processing of remotely-sensed images. John Willy and Son Inc.

Munte, L., Runtuwene, M. R., \& Citraningtyas, G. (2015). Aktivitaas antioksidan dari ekstrak daun prasman (Eupatorium triplinerve Vahl.). Pharmacon, 4(3), 41-50. Tersedia dari https://ejournal.unsrat.ac.id/index.php/pharma con/article/view/8836

National Honey Board. (2006). pH and Acids in Honey. Tersedia dari www.nhb.org

Nicolsson, S. W. (2002). Pollination by Passerine Birds: Why Are Nectars So Dilute? Comparative Biochemistry and Physiology Part B: Biochemistry and Molecular Biology, 126(1), S71. https://doi.org/10.1016/S03050491(00)80140-6 
Novandra, A., \& Widnyana, I. M. (2013). Peluang pasar produk perlebahan Indonesia. Disampaikan pada Acara Alih Teknologi, Balai Penelitian Teknologi Hasil Hutan Bukan Kayu. Tersedia dari https://www.fordamof.org/files/PELUANG_PASAR_PRODUK _PERLEBAHAN_INDONESIA.pdf

Pavlova, T., Stamatovska, V., Kalevska, T., Dimov, I., Assistant, G., \& Nakov, G. (2018). Quality characteristic of honey: a Review. Proceeding of University of Ruse, 57, book 10.2. Tersedia dari https://www.researchgate. net/publication/336085951_QUALITY_CHA RACTERISTICS_OF_HONEY_A_REVIEW

Prasetya, B. A. (2014). Perbandingan mutu madu lebah Apis mellifera berdasarkan kandungan gula pereduksi dan non pereduksi di kawasan karet (Hevea brasiliensis) dan rambutan (Nephelium lappaceum). Sarjana Thesis, Universitas Brawijaya, Malang. Tersedia dari http://repository.ub.ac.id/137107/

Putri, A. A., \& Hidajati, N. (2015). Uji aktivitas antioksidan senyawa fenolik ekstrak metanol kulit batang tumbuhan nyiri batu (Xylocarpus moluccensis). UNESA Journal of Chemistry, 4(1), 37-42. Tersedia dari https://jurnalmaha siswa.unesa.ac.id/index.php/unesa-journal-ofchemistry/article/view/11056

Savitri, N. P. T., Hastuti, E. D., Widodo, S., \& Suedy, S. W. A. (2017). Kualitas madu lokal dari beberapa wilayah di Kabupaten Temanggung. Buletin Anatomi dan Fisiologi, 2(1), 58-66. Tersedia dari https://core.ac.uk/ download/pdf/234033487.pdf

Singh, N., \& Bath, P. K. (1997). Quality evaluation of different types of Indian Honey. Food Chemistry, 58(1-2), 129-133. https:// doi.org/10.1016/S0308-8146(96)00231-2

Sobhy, I. S., Baets, D., Goelen, T., Herrera-
Malaver, B., Bosmans, L., Van den Ende, W., Verstrepen, K. J., Wäckers, F., Jacquemyn, H., \& Lievens, B. (2018). Sweet scents: Nectar specialist yeasts enhance nectar attraction of a generalist aphid parasitoid without affecting survival. Frontiers in Plant Science, 9(July), 1-13. https://doi.org/10.3389/fpls.2018.01009

Strum, A. Y., Tang, Q. Q., Sturm, A. \& Tang, G. Q. (1999). The sucrose cleaving enzymes of plants are crucial for development, growth, and carbon partitioning. Trends in Plant Sciencee, 4(10), 401-407. https://doi.org/' 10.1016/S1360-1385(99)01470-3

Swandari, T., Alat, P., Warna, S., \& Derajat, M. (2017). Penggunaan Alat sensor warna untuk menduga derajat dominansi gen penyandi karakter warna buah cabai hasil persilangan. Agroista, 1(2), 1-10. Tersedia dari http:// 36.82.106.238:8885/jurnal/index.php/AGI/arti cle/download/26/25

Ward, R. B. (1963). Method in Carbohydrate Chemistry (Academic P).

Woodson, W. R., \& Wang, H. (1987). Invertases of carnation petals: Partial purification from a Southern Ecuadorian montane forest. Plant Physiology, 71(2), 224-228. https://doi.org/ 10.1111/j.1399-3054.1987.tb02872.x

Wulandari, D. D. (2017). Analisa kualitas madu (keasaman, kadar air, dan kadar gula pereduksi) berdasarkan perbedaan suhu penyimpanan. Jurnal Kimia Riset, 2(1), 16-22. http://dx.doi.org/10.20473/jkr.v2i1.3768

Yeboah-Gyan, K., \& Marfo, E. K. (1998). The colour and mineral composition of honeys produced in major vegetation areas of Ghana. Journal of Apicultural Research, 37(2), 79-84. https://doi.org/10.1080/00218839.1998.11100 958 